\title{
TRANSGENERATIONAL TRANSMISSION OF VIOLENCE AMONG PARENTS OF PRESCHOOL CHILDREN IN CROATIA
}

\author{
Josipa Rikić1, Petrana Beljan², Milan Milošević ${ }^{3}$ Ivan Miškulin ${ }^{4}$, \\ Maja Miškulin ${ }^{4}$ and Aida Mujkić 3
${ }^{1}$ Srebrnjak Children's Hospital; ${ }^{2}$ Zagreb University Hospital Centre; ${ }^{3}$ University of Zagreb, School of Medicine, Andrija Štampar School of Public Health, Zagreb; ${ }^{4}$ Josip Juraj Strossmayer University of Osijek, Faculty of Medicine, Osijek, Croatia

\begin{abstract}
SUMMARY - The aim of this study was to determine whether there is a transgenerational transmission of violence within the family on a sample of parents of preschool children in Croatia, and to identify the factors that increase the likelihood of child abuse. The Child Abuse Questionnaire was self-administered to the sample of 118 parents of preschool children ( 91 mothers and 27 fathers) during February 2013. There were $7.7 \%$ of mothers and 3.8\% of fathers who answered that they slapped their child, while $15.4 \%$ of the fathers answered that they even hit their child with a fist. We found the subjects who were psychologically and/or physically abused in childhood by their parents to have a higher probability of following the exact model of violence on their children. So, children suffer physical violence in larger families from parents who, in turn, suffered physical violence in childhood from their fathers, controlled for all other factors in the model. Children suffer psychological violence from parents who experienced psychological violence from their own parents during childhood, controlled for all other factors in the model. We also found the higher number of family members in a household to be a risk factor for abuse. The study has confirmed that additional interventions are necessary to break the model of transmitting violence from generation to generation.
\end{abstract}

Key words: Child abuse; Physical abuse; Child; Child, preschool; Violence - prevention and control; Croatia

\section{Introduction}

In their famous article, Kempe et al. defined the battered-child syndrome as "... the clinical condition in young children who have received serious physical abuse generally from a parent or foster parent" ${ }^{\prime}$. After Kempe et al. had specified the battered-child syndrome, the awareness of other forms of maltreatment has also increased. Child abuse and neglect (CAN) is defined as: "... all forms of physical and emotional ill

Correspondence to: Prof. Maja Miškulin, MD, PhD, Faculty of Medicine, Josip Juraj Strossmayer University of Osijek, Cara Hadrijana 10E, HR-31000 Osijek, Croatia

E-mail: maja.miskulin@mefos.hr

Received September 8, 2016, accepted February 23, 2017 treatment, sexual abuse, neglect, and exploitation that results in actual or potential harm to the child's health, development or dignity"2. Violence against children in the family may frequently take place in the context of discipline and takes the form of physical or corporal punishment ${ }^{3}$. Harsh treatment and punishment in the family are common in both industrialized and developing countries, and violence as such happens everywhere, in every country and society and across all social groups ${ }^{4}$. According to the UNICEF estimate, between 133 and 275 million children worldwide witness domestic violence annually $y^{5}$. The problem of physical, emotional and sexual abuse of children, as well as their being neglected, is present in all environments, but it has usually been hidden and held as a family secret ${ }^{6}$. 
Some forms of violent behavior are passed down through generations and are part of everyday life as something completely normal ${ }^{7}$. Emotional abuse is a form of violence that leaves most trace on the child. A mentally abused child is depressed, does not fit well into the social environment, is uninterested in a game, and is often withdrawn or aggressive. Long-term physical violence disrupts children's day-to-day growing up and creates frustration and dissatisfaction with oneself. If parents do not provide children with their basic needs, such as adequate food, adequate clothing, heat and medical care, then they are neglecting their child. Leaving children too young to fend for themselves unattended is also a form of negligence. The exposure of children to violence in their homes on a frequent basis, usually through fights between parents, can severely affect the child's well-being, personal development and social interaction in childhood and adulthood ${ }^{5,89}$. Despite numerous efforts of various humanitarian organizations around the world, we still witness extreme and bizarre cases of child abuse by their parents, relatives, friends or strangers, as reported by the media on a daily basis. One of the most common characteristics of the abusers is that they were also victims of violence. Transgenerational transmission of violence, which implies passing on aggressive behavior to the next generation is becoming recognized as an essential factor working against the psychological well-being and social functioning of descendants ${ }^{10}$. Experienced childhood abuse enhances the risk of mental disorders ${ }^{11}$, as well as the likelihood of future violent offenses and domestic violence ${ }^{12,13}$.

During the past fifteen years, child abuse and neglect have been recognized as an increasingly prevalent public health issue in Croatia. According to the available data, abuse rates in Croatia seem to be rather similar to those in western Europe and USA or worse, with additional risk factors such as unemployment, financial problems, poverty, social isolation and stress levels being more common in not fully revived postwar economies ${ }^{2}$.

The aim of this study was to analyze the types of abuse towards children and the factors that increase the likelihood of such behavior, as well as to find if there is a transgenerational transmission of violence within the family on a sample of parents of preschool children in Croatia.

\section{Subjects and Methods}

\section{Study design}

This cross-sectional study was conducted during February 2013 and data for this study were derived from a convenience sample of parents of preschool children from the Zagreb area, Croatia.

\section{Subjects}

The researchers approached all four kindergartens in the Stenjevec district of the City of Zagreb and two out of four kindergartens agreed to participate in this study, thus forming a convenience sample of kindergartens. The participants (parents of children from these two Zagreb public kindergartens) participated in the study on a voluntary basis. In these two public kindergartens from Stenjevec district of the City of $\mathrm{Za}^{-}$ greb, there were alltogether 450 parents available for participation in the study. The recruitment procedure consisted of several activities, as follows: announcement of the study on each kindergarten public board, meeting of researchers with the kindergarten teachers in order to explain them the study objectives and protocol, distribution of the questionnaires anonymously to the parents (envelopes without names) by researcher each morning during February 2013. Out of 450 parents asked to participate in the study, 118 parents agreed to participate, yielding a response rate of $26.2 \%$ $(118 / 450)$.

\section{Questionnaire}

The Child Abuse Questionnaire was used for data collection. The questionnaire was anonymous. The first part of the questionnaire referred to the parents' own childhood experiences and their socio-demographic characteristics. The second part of the questionnaire referred to the methods used in upbringing their own child. Participants were asked to mark the appropriate frequency of offered behavior with an "X", (never, sometimes, often), or to add/circle one of the answers where requested. After completing it, the parents were asked to place the questionnaire in sealed boxes.

The study was approved by the Ethics Committee of the University of Zagreb School of Medicine.

\section{Statistics}

Upon confirming the normality of data distribution by Kolmogorov-Smirnov test, all data were pro- 
cessed by the methods of descriptive statistics. The proportions were calculated and compared by use of $\chi^{2}$-test for independent samples. Univariate comparison was also performed. In addition, binary logistic regression was performed to assess the impact of a number of factors on the likelihood that children suffered physical and psychological violence. Outcomes (physical and psychological violence) were defined as combined variable if any of the previous variables were positive regarding physical (hitting, slapping, throwing, harming in any physical way) and psychological violence, regardless of the number of items that were positive and their frequencies. In all statistical analyses, two-sided $p$ values of 0.05 were considered significant. Statistical analysis was done by the SPSS Statistical Package for Windows, version 13.0 (SPSS Inc., Chicago, IL, USA).

\section{Results}

The study included 118 participants (91 mothers and 27 fathers). Socio-demographic characteristics of the participants are shown in Table 1 . The educational level of participants was higher than the overall population of Croatia. In addition, the percentage of employment was also higher than the population average.

Parents' upbringing methods are presented in Table 2. As shown in Table 2, 47.3\% of the mothers and $26.9 \%$ of the fathers answered they yelled at their child for no purpose. Slapping was also reported; $7.7 \%$ of the mothers and $3.8 \%$ of the fathers answered they slapped their child, whereas $15.4 \%$ of the fathers answered that they even hit their child with a fist. Aside from abusing their child, parents were often violent towards other family members; $19.8 \%$ of the mothers and $15.4 \%$ of the fathers answered they criticized, insulted, or yelled without reason on other family members. Arguing with a spouse was frequent in the participants' families; $74.4 \%$ of the mothers and $61.6 \%$ of the fathers answered they used to argue with their wife or husband.

Univariate analysis of physical violence is presented in Table 3. Results showed that a significantly higher proportion of parents who had suffered physical violence from their own fathers and mothers, as well as psychological violence from their mothers abused their child physically. Univariate analysis of psychological violence is presented in Table 4. Results showed that
Table 1. Socio-demographic characteristics of study sample $(N=118)$

\begin{tabular}{|c|c|c|c|}
\hline \multirow{3}{*}{ Parents } & & $\mathrm{n}$ & $\%$ \\
\hline & Mother & 91 & 77.1 \\
\hline & Father & 27 & 22.9 \\
\hline \multirow[t]{2}{*}{ Age group (yrs) } & $\leq 35$ & 62 & 57.9 \\
\hline & $>35$ & 45 & 42.1 \\
\hline \multirow[t]{2}{*}{ Marital status } & Married & 103 & 87.3 \\
\hline & Single & 15 & 12.7 \\
\hline \multirow[t]{4}{*}{ Education } & Elementary school & 6 & 5.1 \\
\hline & High school & 51 & 43.2 \\
\hline & University & 54 & 45.8 \\
\hline & $\mathrm{PhD}$ & 7 & 5.9 \\
\hline \multirow[t]{2}{*}{ Employment } & Employed & 100 & 84.7 \\
\hline & Unemployed & 18 & 15.3 \\
\hline \multirow{6}{*}{$\begin{array}{l}\text { Number } \\
\text { of family } \\
\text { members }\end{array}$} & 2 & 5 & 4.3 \\
\hline & 3 & 34 & 29.1 \\
\hline & 4 & 59 & 50.4 \\
\hline & 5 & 10 & 8.5 \\
\hline & 6 & 4 & 3.4 \\
\hline & 7 & 5 & 4.3 \\
\hline \multirow{6}{*}{$\begin{array}{l}\text { Number } \\
\text { of children }\end{array}$} & 1 & 39 & 33.3 \\
\hline & 2 & 61 & 52.1 \\
\hline & 3 & 12 & 10.3 \\
\hline & 4 & 3 & 2.6 \\
\hline & 5 & 1 & 0.9 \\
\hline & 9 & 1 & 0.9 \\
\hline \multirow{5}{*}{$\begin{array}{l}\text { Number } \\
\text { of children } \\
\text { younger } \\
\text { than } 18\end{array}$} & 1 & 40 & 34.8 \\
\hline & 2 & 61 & 53.0 \\
\hline & 3 & 10 & 8.7 \\
\hline & 4 & 3 & 2.6 \\
\hline & 9 & 1 & 0.9 \\
\hline \multirow[t]{4}{*}{ Household } & $\begin{array}{l}\text { Living in own place } \\
\text { property }\end{array}$ & 79 & 66.9 \\
\hline & Renting & 18 & 15.3 \\
\hline & Together with parents & 11 & 9.3 \\
\hline & Other & 10 & 8.5 \\
\hline \multirow{3}{*}{$\begin{array}{l}\text { Economic } \\
\text { status }\end{array}$} & Lower than average & 18 & 15.4 \\
\hline & Average & 92 & 78.6 \\
\hline & Higher than average & 7 & 6.0 \\
\hline
\end{tabular}

parents who had suffered psychological violence from their fathers and mothers psychologically abused their child more often. 
Table 2. Differences in attitudes and behavior towards children among mothers and fathers

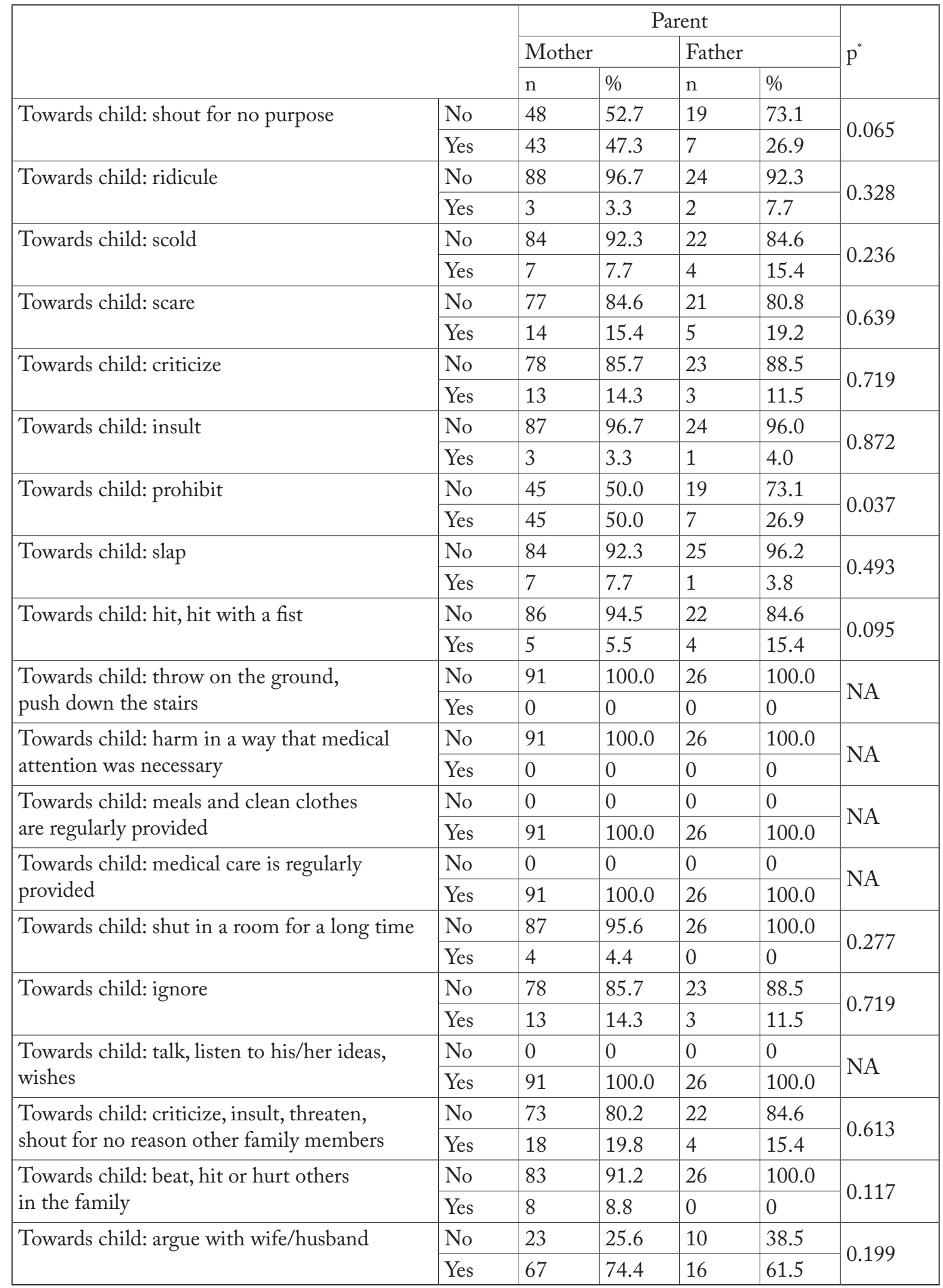

${ }^{2} \chi^{2}$-test; NA $=$ not applicable 
Table 3. Physical violence towards children

\begin{tabular}{|c|c|c|c|c|c|c|c|c|}
\hline & \multicolumn{4}{|c|}{ Physical violence towards children } & \multirow{3}{*}{$\chi^{2}$} & \multirow{3}{*}{ df } & \multirow{3}{*}{$\mathrm{p}^{*}$} \\
\hline & & \multicolumn{2}{|c|}{ No } & \multicolumn{2}{|c|}{ Yes } & & & \\
\hline & & $\mathrm{n}$ & $\%$ & $\mathrm{n}$ & $\%$ & & & \\
\hline \multirow{2}{*}{$\begin{array}{l}\text { Psychological violence } \\
\text { grandfather towards parent }\end{array}$} & No & 43 & 89.6 & 5 & 10.4 & \multirow{2}{*}{1.85} & \multirow{2}{*}{1} & \multirow{2}{*}{0.174} \\
\hline & Yes & 48 & 80.0 & 12 & 20.0 & & & \\
\hline \multirow{2}{*}{$\begin{array}{l}\text { Psychological violence } \\
\text { grandmother towards parent }\end{array}$} & No & 49 & 92.5 & 4 & 7.5 & \multirow{2}{*}{4.23} & \multirow{2}{*}{1} & \multirow{2}{*}{0.04} \\
\hline & Yes & 48 & 78.7 & 13 & 21.3 & & & \\
\hline \multirow{2}{*}{$\begin{array}{l}\text { Physical violence grandfather } \\
\text { towards parent }\end{array}$} & No & 64 & 94.1 & 4 & 5.9 & \multirow{2}{*}{12.49} & \multirow{2}{*}{1} & \multirow{2}{*}{$<0.001$} \\
\hline & Yes & 29 & 69.0 & 13 & 31.0 & & & \\
\hline \multirow{2}{*}{$\begin{array}{l}\text { Physical violence grandmother } \\
\text { towards parent }\end{array}$} & No & 57 & 91.9 & 5 & 8.1 & \multirow{2}{*}{5.02} & \multirow{2}{*}{1} & \multirow{2}{*}{0.025} \\
\hline & Yes & 40 & 76.9 & 12 & 23.1 & & & \\
\hline
\end{tabular}

*univariate comparison

Table 4. Psychological violence towards children

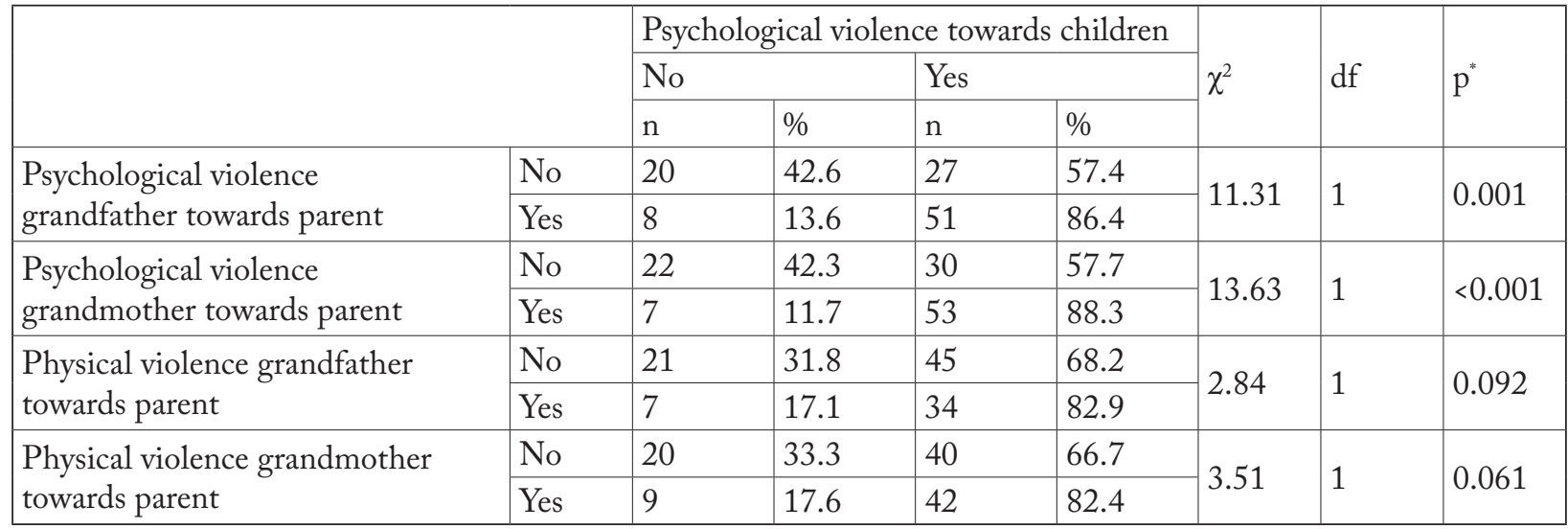

*univariate comparison

The models contained 12 independent variables (parental gender, age, marital status, education, employment, number of family members living together, economic status, place of residence, and parental experience of psychological and physical violence during childhood). The full models were statistically significant $(\mathrm{p}=0.011$ and $\mathrm{p}=0.042$, respectively), indicating that it was possible to distinguish between children who did and did not suffer physical and psychological violence.

Binary logistic regression was performed to assess the impact of a number of factors on the likelihood that children suffered physical (Table 5) and psychological (Table 6) violence. The model for physical violence as a whole explained between 25.4\% (Cox and Snell R square) and 44.8\% (Nagelkerke R squared) of the variance in physical violence status, and correctly classified $91.7 \%$ of cases. As shown in Table 5, two of the independent variables made a unique, statistically significant contribution to the model, i.e. the number of family members living together $(\mathrm{OR}=2.83,95 \% \mathrm{CI}$ : 1.14-7.01) and physical violence of grandfather towards parent (OR=7.14, 95\% CI: $1.40-36.33)$. This indicated that children suffered physical violence in larger families from parents who, in turn, had suffered physical violence in childhood from their fathers, controlled for all other factors in the model.

The model for psychological violence as a whole explained between 22.8\% (Cox and Snell R square) and $33.5 \%$ (Nagelkerke $\mathrm{R}$ squared) of the variance in psychological violence status, and correctly classified $78.7 \%$ of cases. As shown in Table 6, two of the inde- 
Table 5. Predictors of physical violence towards children

\begin{tabular}{|l|l|l|l|l|}
\hline & \multirow{3}{*}{ OR } & \multicolumn{2}{|l|}{$95 \%$ CI } & \multirow{2}{*}{$\mathrm{p}^{*}$} \\
\cline { 3 - 5 } & & Lower & Upper & \\
\hline Age (years) & 0.82 & 0.64 & 1.04 & 0.095 \\
\hline Father & 7.00 & 0.97 & 50.64 & 0.054 \\
\hline Unmarried & 2.43 & 0.16 & 35.98 & 0.517 \\
\hline Higher education & 6.13 & 0.71 & 52.89 & 0.099 \\
\hline Unemployed & 0.84 & 0.05 & 15.60 & 0.907 \\
\hline $\begin{array}{l}\text { Number of family } \\
\text { members }\end{array}$ & 2.83 & 1.14 & 7.01 & 0.025 \\
\hline $\begin{array}{l}\text { Living in own } \\
\text { property }\end{array}$ & 1.05 & 0.06 & 18.32 & 0.974 \\
\hline Renting & 0.85 & 0.04 & 17.99 & 0.915 \\
\hline $\begin{array}{l}\text { Together } \\
\text { with parents }\end{array}$ & 8.11 & 0.60 & 110.00 & 0.116 \\
\hline Other & 1.58 & 0.16 & 15.21 & 0.692 \\
\hline Economic status & 1.93 & 0.35 & 10.44 & 0.448 \\
\hline $\begin{array}{l}\text { Psychological } \\
\text { violence grandfather } \\
\text { towards parent }\end{array}$ & 1.93 & 0.30 & 12.33 & 0.489 \\
\hline $\begin{array}{l}\text { Psychological } \\
\text { violence } \\
\text { grandmother } \\
\text { towards parent }\end{array}$ & 0.24 & 12.95 & 0.578 \\
\hline $\begin{array}{l}\text { Physical violence } \\
\text { grandfather towards } \\
\text { parent }\end{array}$ & 7.14 & 1.40 & 36.33 & 0.018 \\
\hline $\begin{array}{l}\text { Physical violence } \\
\text { grandmother } \\
\text { towards parent }\end{array}$ & non & & & 0.475 \\
\hline
\end{tabular}

*binary logistic regression; OR = odds ratio; $95 \% \mathrm{CI}=95 \%$ confidence interval

pendent variables made a unique, statistically significant contribution to the model, i.e. psychological violence of grandfather towards parent $(\mathrm{OR}=4.76,95 \%$ CI: 1.34-16.91) and psychological violence of grandmother towards parent (OR=4.33, 95\% CI: 1.10 17.04). This indicated that children suffered psychological violence from parents who had experienced psychological violence from their parents during childhood, controlled for all other factors in the model.

\section{Discussion}

Since the article by Kempe et al. from the $1960 \mathrm{~s}^{1}$, ever more public and professional attention has been
Table 6. Predictors of psychological violence towards children

\begin{tabular}{|l|l|l|l|l|}
\hline & \multirow{3}{*}{ OR } & \multicolumn{2}{|l|}{$95 \%$ CI } & \multirow{2}{*}{$\mathrm{p}^{*}$} \\
\cline { 3 - 5 } & 1.07 & Lower & Upper & \\
\hline Age (years) & 0.93 & 1.22 & 0.353 \\
\hline Father & 0.74 & 0.13 & 4.22 & 0.732 \\
\hline Unmarried & 0.35 & 0.09 & 1.33 & 0.123 \\
\hline Higher education & 0.96 & 0.12 & 7.69 & 0.972 \\
\hline Unemployed & 1.67 & 0.70 & 3.99 & 0.248 \\
\hline $\begin{array}{l}\text { Number of family } \\
\text { members }\end{array}$ & 2.07 & 0.35 & 12.12 & 0.420 \\
\hline $\begin{array}{l}\text { Living in own } \\
\text { property }\end{array}$ & 0.64 & 0.07 & 6.14 & 0.698 \\
\hline Renting & 2.41 & 0.19 & 30.56 & 0.499 \\
\hline $\begin{array}{l}\text { Together with } \\
\text { parents }\end{array}$ & 1.82 & 0.41 & 8.07 & 0.428 \\
\hline Other & 4.76 & 1.34 & 16.91 & 0.016 \\
\hline Economic status & & 1.10 & 17.04 & 0.036 \\
\hline $\begin{array}{l}\text { Psychological } \\
\text { violence grandfather } \\
\text { towards parent }\end{array}$ & 0.56 & 0.13 & 2.50 & 0.447 \\
\hline $\begin{array}{l}\text { Psychological } \\
\text { violence } \\
\text { grandmother } \\
\text { towards parent }\end{array}$ & 0.42 & 5.67 & 0.517 \\
\hline $\begin{array}{l}\text { Physical violence } \\
\text { grandfather towards } \\
\text { parent }\end{array}$ & 1.54 & 1.33 \\
\hline $\begin{array}{l}\text { Physical violence } \\
\text { grandmother } \\
\text { towards parent }\end{array}$ & 0.733 \\
\hline
\end{tabular}

binary logistic regression; $\mathrm{OR}=$ odds ratio; $95 \% \mathrm{CI}=95 \%$ confidence interval

focused on violence, especially in the cases where the victims are children. There are many issues regarding violence towards children. Exposure to violence describes two types of experiences, i.e. direct victimization and witnessing violence ${ }^{14}$. Both types of exposure during childhood put children in a group at a higher risk of adverse proximal and distal outcomes related to traumatic stress. Children who directly experience violence through abuse or other situations have a greater likelihood of experiencing traumatic symptomatology during childhood, adolescence, and even later in life ${ }^{15}$. Child abuse is not only a problem at the family level, but at the society level as well because of serious and 
long term consequences. It is important to recognize risk factors and to intervene in order to break the abuse-transferring cycle to the next generation ${ }^{16} . \mathrm{Nu}^{-}$ merous studies have demonstrated that, among other risk factors, our own experience of abuse in childhood is a risk factor of transferring the pattern to the next generation ${ }^{10,17-21}$.

The results of this study showed relatively high figures for different abusive behavior towards children. For example, $7.7 \%$ of the mothers and $3.8 \%$ of the fathers answered that they slapped their child, whereas $15.4 \%$ of the fathers answered that they even hit their child with a fist. The abuser's own childhood abuse was recognized as a risk factor. According to binary logistic regression, the parents who had been exposed to physical violence in childhood, especially from their fathers, transferred the same pattern of behavior to their children. The larger the number of family members, the higher was the risk of physical abuse of the child. In univariate comparison, psychological violence of grandmother towards parent was also shown to be a risk for physical violence towards children in the next generation. Regarding psychological violence, the same type of violence in the previous generation from grandfather and grandmother was the risk for the children in the next generation, and the results were the same in univariate comparison and binary logistic regression. The results of another study showed that onethird of child victims grew up to continue the pattern of seriously inept, neglectful, or abusive parenting; another third remained vulnerable to the effects of social pressure on the likelihood for them to become abusive parents ${ }^{22}$. Other findings indicated that childhood victimization increased the risk of physical and sexual assault/abuse, kidnapping/stalking, and having a family friend murdered or committing suicide ${ }^{23}$. Parents who had experienced multiple acts of abuse and at least one physical impact were more likely to become abusive than other parents ${ }^{24}$. Everyday environment has a huge influence on the child's growing up and on creating the picture about life values and behaving properly in specific situations ${ }^{19}$. Kwong et al. report that growing up in an abusive family environment can teach the child that the use of violence and aggression is a viable means for dealing with interpersonal conflict, which can increase the likelihood that the cycle of violence will continue when the child reaches adulthood ${ }^{12}$.
A limitation to our study was low response, with only $26.2 \%$ of respondents, indicating that this is a very sensitive issue. Participants in our study had a higher economic status and educational level than the Croatian average, so we can assume that the abuserelated facts about parenting are even more unfavorable among lower social and educational classes. Namely, recent literature dealing with the issue of child health emphasizes the facts that low level of parent or guardian education is a personal risk factor for children injurying ${ }^{25}$ and that in children from families with a lower level of parental education, development of speech and language skills, as well as other cognitively related abilities progress slowly in early childhood $^{26}$. Despite evident improvements, additional efforts and interventions are needed to recognize the devastating effects of child abuse and to implement successful measures to stop children's suffering and all other adverse consequences of child abuse.

In conclusion, in this study, we found that children suffered violence more often from parents who had experienced childhood violence from their own parents, in a way that the type of experienced violence influenced the pattern of violence towards their children. Those parents who experienced physical violence are more prone to abusing their children in the same way, and the same holds for psychological violence.

\section{Acknowledgments}

The survey was conducted as part of a project entitled Child Injury Prevention and Safety Promotion, supported by the University of Zagreb, Zagreb, Croatia. This project also received partial support from the University of Iowa Injury Prevention Research Center (CDC CCR 703640) and the University of Iowa International Trauma Training Program (NIH FIC 2D43 TW007261). The contents are solely the responsibility of the authors and do not necessarily represent the official views of the National Institutes of Health, Fogarty International Center.

\section{References}

1. Kempe CH, Silverman FN, Steele BF, Droegemueller W, Silver HK. The battered-child syndrome. JAMA. 1984;251 (24):3288-94.

2. Buljan Flander G, Tarabić BN, Čuković-Bagić I. Child Abuse and Neglect: Croatian Dental Practitioners' Experience and Knowledge. Alcohol Psychiatry Res. 2015;51:127-36. 
3. Durrant JE. Corporal punishment: prevalence, predictors and implications for child behaviour and development. In: Hart SN, editor. Eliminating Corporal Punishment: The way forward to constructive child discipline. Paris: UNESCO Publishing; 2005. p. 49-90.

4. Lilleston PS, Goldmann L, Verma RK, McCleary-Sills J. Understanding social norms and violence in childhood: theoretical underpinnings and strategies for intervention. Psychol Health Med. 2017;9:1-13. doi: 10.1080/13548506.2016.1271954

5. World Health Organization. Global Estimates of Health Consequences due to Violence against Children. Background paper for the United Nations Study on Violence against Children. Geneva: World Health Organization; 2006.

6. Rakovec-Felser Z, Vidovič L. Maternal perceptions of and responses to child sexual abuse. Zdr Varst. 2016;55(2):114-20. doi: 10.1515/sjph-2016-0017

7. Lecic-Tosevski D, Draganic-Gajic S, Pejovic-Milovancevic M, Popovic-Deusic S, Christodoulou N, Botbol M. Child is father of the man: child abuse and development of future psychopathology. Psychiatriki. 2014;25(3):185-91.

8. Kavanaugh BC, Dupont-Frechette JA, Jerskey BA, Holler KA. Neurocognitive deficits in children and adolescents following maltreatment: neurodevelopmental consequences and neuropsychological implications of traumatic stress. Appl Neuropsychol Child. 2017;6(1):64-78. doi: 10.1080/21622965.2015. 1079712

9. Hillberg T, Hamilton-Giachritsis C, Dixon L. Review of metaanalyses on the association between child sexual abuse and adult mental health difficulties: a systematic approach. Trauma Violence Abuse. 2011;12(1):38-49. doi: 10.1177/152483801 0386812

10. Crombach A, Bambonyé $\mathrm{M}$. Intergenerational violence in $\mathrm{Bu}-$ rundi: experienced childhood maltreatment increases the risk of abusive child rearing and intimate partner violence. Eur J Psychotraumatol. 2015;6. doi: 10.3402/ejpt.v6.26995

11. Teicher MH, Samson JA. Childhood maltreatment and psychopathology: a case for ecophenotypic variants as clinically and neurobiologically distinct subtypes. Am J Psychiatry. 2013; 170(10):1114-33. doi: 10.1176/appi.ajp.2013.12070957

12. Kwong M, Bartholomew K, Henderson A, Trinke S. The intergenerational transmission of relationship violence. J Fam Psychol. 2003;17(3):288-301. doi:10.1037/0893-3200.17.3.288

13. Weaver CM, Borkowski JG, Whitman TL. Violence breeds violence: childhood exposure and adolescent conduct problems. J Community Psychol. 2008;36(1):96-112. doi: 10.1002/jcop. 20219
14. McCloskey LA, Figueredo AJ, Koss MP. The effects of systemic family violence on children's mental health. Child Development. 1995;66(5):1239-61. doi: 10.2307/1131645

15. Finkelhor D, Turner H, Ormrod R, Hamby SL. Violence, abuse, and crime exposure in a national sample of children and youth. Pediatrics. 2009;124(5):1411-23. doi: 10.1542/peds. 2009-0467

16. Boney-McCoy S, Finkelhor D. Psychosocial sequelae of violent victimization in a national youth sample. J Consult Clin Psychol. 1995;63(5):726-36. doi: 10.1037/0022-006X.63.5.726

17. Ertem IO, Leventhal JM, Dobbs S. Intergenerational continuity of child physical abuse: how good is the evidence? Lancet. 2000;356(9232):814-9. doi: 10.1016/S0140-6736(00)02656-8

18. Newcomb MD, Locke TF. Intergenerational cycle of maltreatment: a popular concept obscured by methodological limitations. Child Abuse Negl. 2001;25(9):1219-40. doi: 10.1016/ S0145-2134(01)00267-8

19. Pears K, Capaldi D. Intergenerational transmission of abuse: a two-generational prospective study of an at-risk sample. Child Abuse Negl. 2001;25(11):1439-61. doi: 10.1016/S01452134(01)00286-1

20. Umeda M, Kawakami N, Kessler RC, Miller E; World Mental Health Japan Survey Group 2002-2006. Childhood adversities and adult use of potentially injurious physical discipline in Japan. J Fam Violence. 2015;30(4):515-27. doi: 10.1007/ s10896-015-9692-z

21. Milaniak I, Widom CS. Does child abuse and neglect increase risk for perpetration of violence inside and outside the home? Psychol Violence. 2015;5(3):246-55. doi: 10.1037/a0037956

22. Fowler PJ, Tompsett CJ, Braciszewski JM, Jacques-Tiura AJ, Baltes BB. Community violence: a meta-analysis on the effect of exposure and mental health outcomes of children and adolescents. Dev Psychopathol. 2009;21(1):227-59. doi: 10.1017/ S0954579409000145

23. Oliver JE. Intergenerational transmission of child abuse: rates, research, and clinical implications. Am J Psychiatry. 1993;150 (9):1315-24.

24. Widom C, Czaja S, Dutton M. Childhood victimization and lifetime revictimization. Child Abuse Negl. 2008;32(8): 785-96. doi: 10.1016/j.chiabu.2007.12.006

25. Mihić J, Rotim K, Marcikić M, Smiljanić D. Head injury in children. Acta Clin Croat. 2011;50(4):539-48.

26. Matijević Mikelić V, Bartolović J, Košiček T, Crnković M. Educated parent as a key member of rehabilitation team. Acta Clin Croat. 2011;50(4):469-73. 


\section{Sažetak \\ TRANSGENERACIJSKI PRIJENOS NASILJA KOD RODITELJA PREDŠKOLSKE DJECE U HRVATSKOJ}

\section{J. Rikić, P. Beljan, M. Milošević, I. Miškulin, M. Miškulin i A. Mujkić}

Cilj ovoga istraživanja bio je utvrditi postoji li transgeneracijski prijenos nasilja u obitelji na uzorku roditelja djece predškolske dobi u Republici Hrvatskoj te identificirati čimbenike koji povećavaju vjerojatnost zlostavljanja djece. Upitnik o zlostavljanju djece samostalno je ispunjavalo 118 roditelja djece predškolske dobi (91 majki i 27 očeva) tijekom veljače 2013. godine. Bilo je 7,7\% majki i 3,8\% očeva koji su odgovorili da su ošamarili svoje dijete, dok je $15,4 \%$ očeva odgovorilo da su čak i udarili svoje dijete šakom. Otkrili smo da su ispitanici koje su bili psihički i/ili fizički zlostavljani u djetinjstvu od strane vlastitih roditelja imali veću vjerojatnost slijediti takav model nasilja prema svojoj djeci. Istraživani model prijenosa nasilja u obitelji pokazao je kako su djeca češće doživjela fizičko nasilje u većim obiteljima, i to od roditelja koji su, pak, pretrpjeli fizičko nasilje u djetinjstvu od svojih očeva, kontrolirano za sve ostale čimbenike u modelu. Model prijenosa nasilja u obitelji pokazao je nadalje kako su djeca češće pretrpjela psihičko nasilje od roditelja koji su sami pretrpjeli psihičko nasilje od vlastitih roditelja u djetinjstvu, kontrolirano za sve ostale čimbenike u modelu. Također je otkriveno da je veći broj članova obitelji čimbenik rizika za zlostavljanje djece. Istraživanje je pokazalo kako su potrebne daljnje intervencije kojima bi se razbio utvrđeni model prijenosa nasilja iz generacije u generaciju.

Ključne riječi: Dijete, zlostavljanje; Fizičko nasilje; Dijete; Dijete, predskolsko; Nasilje-prevencija i kontrola; Hrvatska 